\title{
11. GLASS INCLUSIONS WITH MICROGLOBULES IN PLAGIOCLASE AND PYROXENE PHENOCRYSTS OF VOLCANIC ROCKS FROM THE BONIN ARC, LEG $126^{1}$
}

\author{
Teruo Watanabe, ${ }^{2}$ Tadao Hirama, ${ }^{3}$ Makoto Yuasa, ${ }^{4}$ Shoichi Terada, ${ }^{2}$ and Kantaro Fujioka ${ }^{5}$
}

\begin{abstract}
The chemical composition of glass inclusions in phenocrystic plagioclase and pyroxene from Sites 792 and 793, drilled during Ocean Drilling Program Leg 126 in the Bonin Arc, is examined. Immiscible liquid, which is preserved as glass inclusions with unmixed textures in plagioclase, is observed in a high-magnesian andesite, which suggests an important role of liquid immiscibility in the fractionation of high-magnesian andesite. In other andesitic rocks $\left(\mathrm{SiO}_{2}=57-60 \mathrm{wt} \%\right)$, such unmixed textures of glass inclusions in calcic plagioclase with a similar percentage of An (around $80 \%$ ) is not found. The degree of fractionation and mixing of liquid are inferred from the glass composition in pyroxene.
\end{abstract}

\section{INTRODUCTION}

Komatsu and Yajima's (1970) electron microprobe analysis (EMPA) of the chemical composition of glass inclusions in phenocrysts of volcanic rocks revealed the existence of rock series and residue that resulted from the crystallization of trapped liquid in host phenocrysts. Anderson (1973) examined glass inclusions and discussed their significance in terms of the volatile components of magma. Anderson (1976) also studied glasses in matrix and glass inclusions of volcanic rocks and stressed the important role of glasses as a tool for the study of magma mixing. Watson (1976) estimated the amount of liquid composition in a South Atlantic basalt on the basis of composition of glass inclusions. Later, Roedder (1979) discussed comprehensively the origin and significance of glass inclusions during the crystallization of phenocrystic crystals. He also described the microglobules of an immiscible sulfide phase in glass inclusions.

Primary glass inclusions in the phenocrystic crystals reflect a partial compositional trend of evolved magmatic liquid. For example, the compositional variation of glass inclusions plotted on a $\mathrm{CaO}$ $\mathrm{MgO}-\mathrm{Al}_{2} \mathrm{O}_{3}$ diagram indicate the trend produced by mineral fractionation (Watson, 1976). Also, lower $\mathrm{Mg} /\left(\mathrm{Mg}+\mathrm{Fe}\right.$ ) and higher $\mathrm{TiO}_{2}$ in inclusions indicate the existence of olivine fractionation (Dungan and Rhodes, 1978) or ferromagnesian mineral crystallization (Clocchiatti and Massare, 1985). $\mathrm{Cl} / \mathrm{K}_{2} \mathrm{O}$ ratios in glass inclusions indicate the degree of differentiation (Anderson, 1982), and the $\mathrm{CaO} / \mathrm{Na}_{2} \mathrm{O}$ ratio in glass inclusions of olivine can be used to infer the ratio in the primary magma (Falloon and Green, 1986). Dungan and Rhodes (1978) presented evidence for magma mixing on the basis of their study of residual glasses and melt inclusions in basalts from Deep Sea Drilling Project (DSDP) Legs 45 and 46.

The study of volatiles in glass inclusions will reveal the gas composition in magma, which in turn will contribute to the understanding of the mechanism of eruption and the effect of the gas composition on the atmosphere (Saitoh and Kusakabe, 1989). As summarized by Shinohara (1990), total volatiles increase with $\mathrm{SiO}_{2}$ contents in melt inclusions, sulfur decreases with the $\mathrm{SiO}_{2}$ contents, and $\mathrm{Cl}$ contents may reach a maximum at intermediate $\mathrm{SiO}_{2}$ contents (around $60 \%$ ). Thus, the accumulation of data on the occurrence and

\footnotetext{
'Taylor, B., Fujioka, K., et al., 1992. Proc. ODP, Sci. Results, 126: College Station, TX (Ocean Drilling Program).

${ }^{2}$ Department of Geology and Mineralogy, Hokkaido University, Sapporo 060, Japan

${ }^{3}$ Department of Earth Sciences, Hokkaido University, Sapporo 060, Japan.

${ }^{4}$ Geological Survey of Japan, Tsukuba, Ibaraki 305, Japan.

${ }^{5}$ Ocean Research Institute, University of Tokyo, 1-15-1 Minamidai, Nakano, Tokyo 164, Japan (present address: Japan Marine Science and Technology Center, 2-14 Nat sushima, Yokosuka, Kanagowa 238, Japan).
}

composition of glass inclusions is important for understanding the chemistry of magma and the crystallization process.

We describe in this paper the preliminary results from our study of the glass inclusions, mostly $<0.5 \mathrm{~mm}$ in diameter, in plagioclase and pyroxene phenocrysts of arc-volcanic rocks. Microglobules are commonly found in the glass inclusions, but we have not yet found fluid inclusions in the glass inclusion samples that are described in this paper and were collected from Holes 792E and 793B in the Bonin Arc area.

\section{TECTONIC SETTING}

The locations of Sites 792 and 793 are shown in Figure 1. Site 792 is approximately $100 \mathrm{~km}$ from Hichijo-jima to the southeast. Site 793 is located to the northeast of Torishima. Tectonically, Site 792 is situated on the northern extension of the frontal-arc high of Bonin Arc, and Site 793 is located in the forearc basin (Honza and Tamaki, 1985). From the samples obtained during Leg 126, we selected four pieces (Samples A, B, C, and D) that commonly contain glass inclusions with microglobules in plagioclase and pyroxene phenocrysts. Sample A is from Hole 793B and the other samples are from Hole 792E. Samples A, $\mathrm{B}$, and $\mathrm{C}$ were collected from the acoustic basement underlying Oligocene rocks, and Sample D is from upper Oligocene rocks rich in volcanic pebbles.

\section{DESCRIPTION OF ROCKS}

A brief description of the four samples, based on the Leg 126 Initial Reports and our study, are presented here.

\section{Sample A}

Sample 126-793B-105R-1, 74-78 cm (porphyritic andesite), is part of a thick pillow lava. It has the same lithology of analyzed rocks listed in the Initial Reports (Sample 126-793B-105R-1, 127-131 cm). The composition of the latter is shown in Table 1 and is that of high-magnesian andesite of the arc-tholeiite series. The analyzed rock from the basement at Site 793 was situated around $4555 \mathrm{~m}$ below sea level (mbsl). The rock contains phenocrysts of orthopyroxene (approximately 5\%, 0.5-3 mm, euhedral), clinopyroxene $(10 \%-15 \%$, 2-6 mm, euhedral, stellate clusters), and plagioclase (approximately $2 \%, 0.5-1.0 \mathrm{~mm}$, euhedral).

Amygdules, 2-20 mm in diameter, are filled with zeolite and native copper (Taylor, Fujioka, et al., 1990). Zeolite minerals are confirmed as mordenite and dachiardite by X-ray diffraction analysis. Maghemite is contained in the rock. 


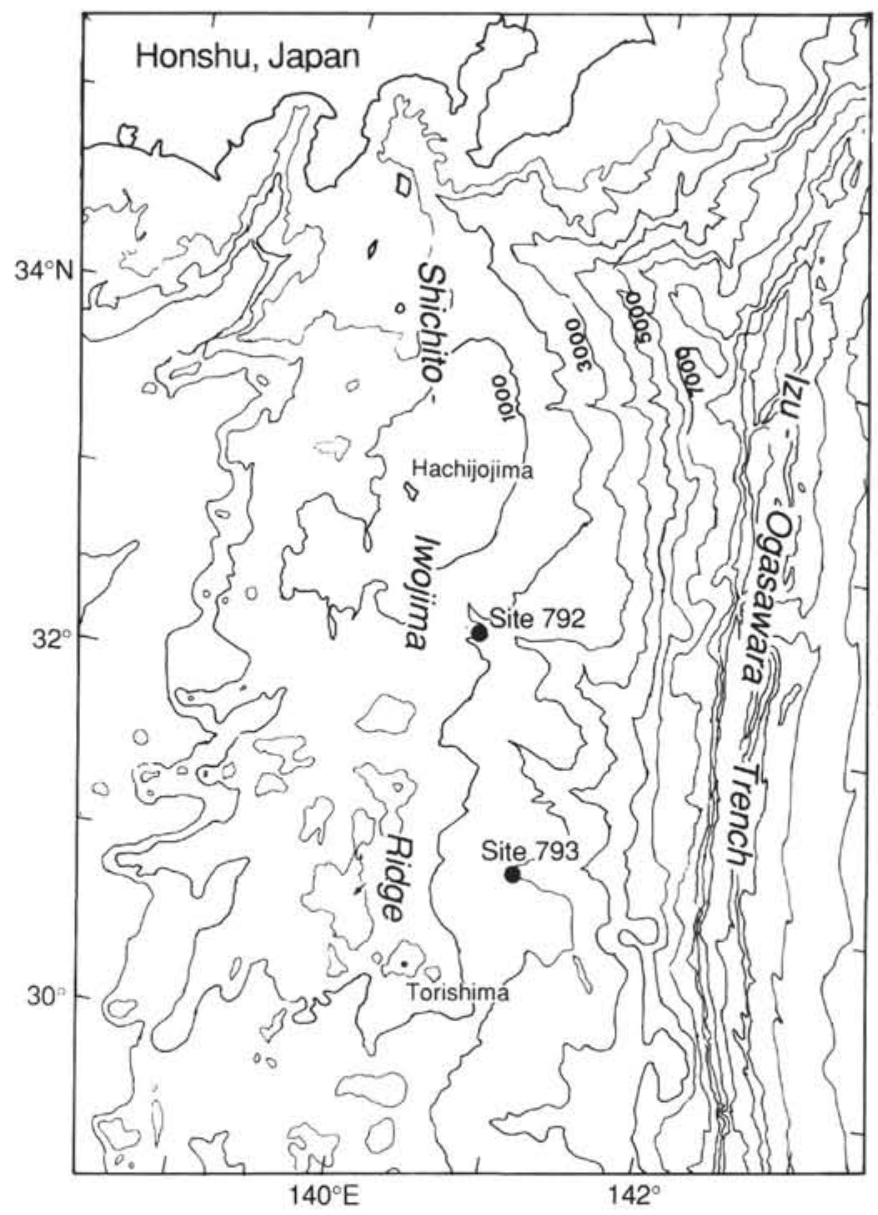

Figure 1. Bathymetric map of the Izu-Bonin Arc between the Shikoku Basin and Izu-Bonin Trench and location of Sites 792 and 793 (after Taylor, Fujioka, et al., 1990).

\section{Sample B}

Sample 126-792E-74R-1, 70-72 cm, is an andesitic hyaloclastic breccia that contains plagioclase-orthopyroxene-clinopyroxene andesite and plagioclase-clinopyroxene-quartz-dacite fragments in a hydrothermally altered glassy matrix. The andesitic hyaloclastite overlies a porphyritic andesite layer, and the andesitic blocks are thought to be compositionally equivalent to the porphyritic andesite, the composition of which is listed in Table 1 (Sample 126-792E-74R$2,53-57 \mathrm{~cm}$ ). Plagioclase is the most predominant phenocrystic mineral in the sample, which was located at $2672 \mathrm{mbsl}$ (water depth, $1787.7 \mathrm{~m})$

\section{Sample C}

Sample 126-792E-71R-1, 107-112 cm (porphyritic andesite), consists of part of a porphyritic andesite unit intercalating thin hyaloclastic layers. Under the microscope, the petrographical characteristics of Sample $\mathrm{C}$ are equivalent to an andesite analyzed by X-ray fluorescence that was described in the Initial Reports (Table 1, Sample 126793B-71R-1, 9-13 cm). The andesite consists of phenocrysts of plagioclase $(35 \%, 0.2-5 \mathrm{~mm}$, euhedral, zoned, and glomeroporphyritic clots), clinopyroxene ( $5 \%, 0.1-5 \mathrm{~mm}$, euhedral), orthopyroxene $(10 \%, 0.1-5 \mathrm{~mm}$, euhedral, mostly replaced by smectite), and magnetite $(1 \%, 0.1-0.5 \mathrm{~mm}$, subhedral). The sample was situated about 2599 mbsl (water depth, $1787.7 \mathrm{~m}$ ).
Table 1. Chemical composition of volcanic rocks from Sites 792 and 793.

\begin{tabular}{|c|c|c|c|c|}
\hline Sample & A & B & $\mathrm{C}$ & D \\
\hline Hole & 793B & $792 \mathrm{E}$ & $792 \mathrm{E}$ & $792 \mathrm{E}$ \\
\hline Core, section & 105R-1 & $74 \mathrm{R}-2$ & $74 \mathrm{R}-1$ & $47 \mathrm{R}-1$ \\
\hline Interval $(\mathrm{cm})$ & $127-131$ & $53-57$ & $9-13$ & $15-20$ \\
\hline \multicolumn{5}{|c|}{ Major elements (wt\%): } \\
\hline $\mathrm{SiO}_{2}$ & 57.00 & 59.91 & 57.48 & 50.14 \\
\hline $\mathrm{TiO}_{2}$ & 0.28 & 0.54 & 0.54 & 0.80 \\
\hline $\mathrm{Al}_{2} \mathrm{O}_{3}$ & 13.07 & 17.50 & 18.92 & 20.94 \\
\hline $\mathrm{FeO}$ & 9.26 & 7.17 & 6.90 & 6.76 \\
\hline $\mathrm{MnO}$ & 0.15 & 0.05 & 0.15 & 0.40 \\
\hline $\mathrm{MgO}$ & 8.53 & 3.41 & 3.28 & 5.56 \\
\hline $\mathrm{CaO}$ & 10.43 & 8.21 & 9.67 & 10.17 \\
\hline $\mathrm{Na}_{2} \mathrm{O}$ & 1.82 & 2.57 & 2.31 & 3.41 \\
\hline $\mathrm{K}_{2} \mathrm{O}$ & 0.44 & 0.20 & 0.23 & 1.23 \\
\hline $\mathrm{P}_{2} \mathrm{O}_{5}$ & 0.01 & 0.04 & 0.11 & 1.07 \\
\hline LOI & 2.57 & 1.44 & 1.01 & 7.04 \\
\hline Total & 100.99 & 99.60 & 99.59 & 100.48 \\
\hline \multicolumn{5}{|c|}{ Trace elements (ppm): } \\
\hline $\mathrm{Zn}$ & 28.8 & 39 & 40 & 41 \\
\hline $\mathrm{Y}$ & 9.6 & 18 & 20 & 22 \\
\hline $\mathrm{Rb}$ & 3.8 & 2.4 & 1.4 & 2 \\
\hline $\mathrm{Sr}$ & 127 & 166 & 176 & 174 \\
\hline $\mathrm{Ba}$ & 17.3 & 28 & 31 & 20 \\
\hline V & 251.5 & 242 & 258 & 256 \\
\hline $\mathrm{Nb}$ & 0.4 & 0.6 & 0.9 & 0.7 \\
\hline $\mathrm{Ni}$ & 36.6 & 6 & 9 & 10 \\
\hline $\mathrm{Cr}$ & 249.2 & 0 & 12 & 13 \\
\hline $\mathrm{Zn}$ & 82.7 & 79 & 86 & 93 \\
\hline $\mathrm{Cu}$ & 7.2 & 39 & 34 & 26 \\
\hline $\mathrm{Ce}$ & - & 7 & 2 & 2 \\
\hline
\end{tabular}

Notes: Data are from Taylor, Fujioka, et al. (1990). LOI = loss on ignition and dash $(-)=$ below detection level.

\section{Sample D}

Sample 126-792E-47R-3, 1-6 cm (volcanic-lithic conglomerate and granule-rich vitric sandstone) consists of part of an upper Oligocene strata. The sedimentary unit consists up to $20 \%$ volcanic pebbles. One of the pebbles displays the basaltic composition shown in Table 1 (Sample 126-792E-47R-1, 15-20 cm).

\section{ANALYTICAL TECHNIQUE FOR GLASS ANALYSIS}

The chemical composition of glass inclusions was obtained by EMPA at the Analytical Laboratory of the Department of Geology and Mineralogy, Hokkaido University. Accelerating voltage was $15 \mathrm{kV}$, beam current was $2 \times 10^{-8} \AA$, and beam size was $2 \mu \mathrm{m}$ in diameter on periclase for small glass inclusions. In this analytical condition, loss of sodium and potassium counts was very significant. Therefore, we estimated sodium and potassium contents on the basis of Ono et al.'s (1976) method (i.e., the contents were inferred from decreasing curves of counts per second as shown in Fig. 2). Calibration curves for sodium (Fig. 3) and potassium between the weight percentage and counts were obtained by standard glass analysis. As already mentioned by Ono et al. (1976), loss of sodium was most significant for glass with high $\mathrm{SiO}_{2}$ contents. However, a $10-\mu \mathrm{m}$ beam for low- $\mathrm{SiO}_{2}$ glass (around $55 \%$ ) did not generate any distinct loss of sodium and potassium. The composition of glass inclusions often yielded low totals, as listed in Tables 2-5. By means of energy-dispersive-systems (EDS) analysis, we were able to determine that no other major elements except for chlorine $(<0.5 \%)$ were present. Sulfur was not positively detected. Hence, we infer that the glass contains only a few percent of water and very small amounts of chlorine. The very fine parts of inclusions were examined by EDS at the Section of Historical Earth Dynamics of the Department of Geology and Mineralogy, 

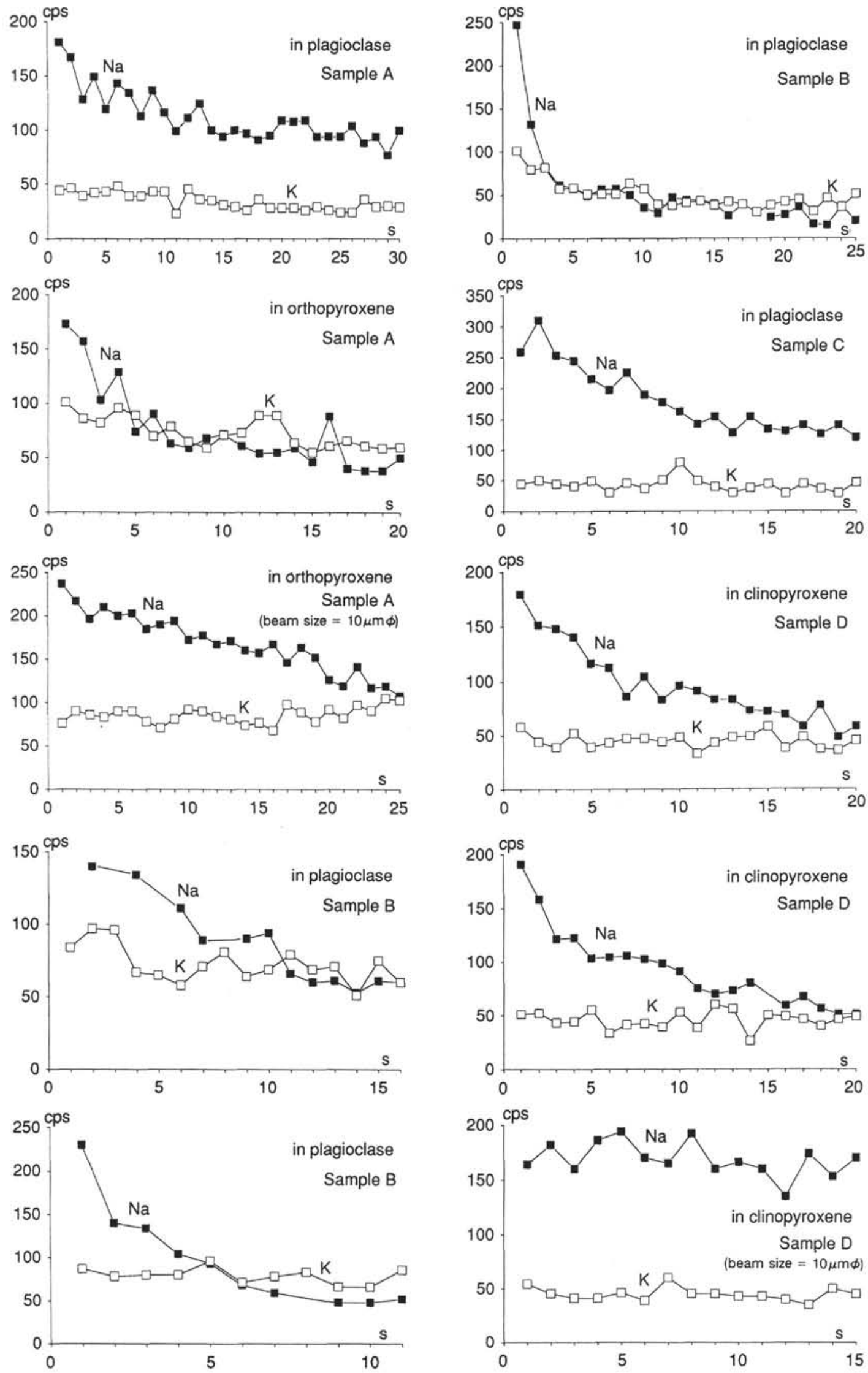

Figure 2. Representative graphs showing intensity variation (counts per second) of sodium and potassium with time (seconds) for glass inclusions in Sample A, B, C, and D. 

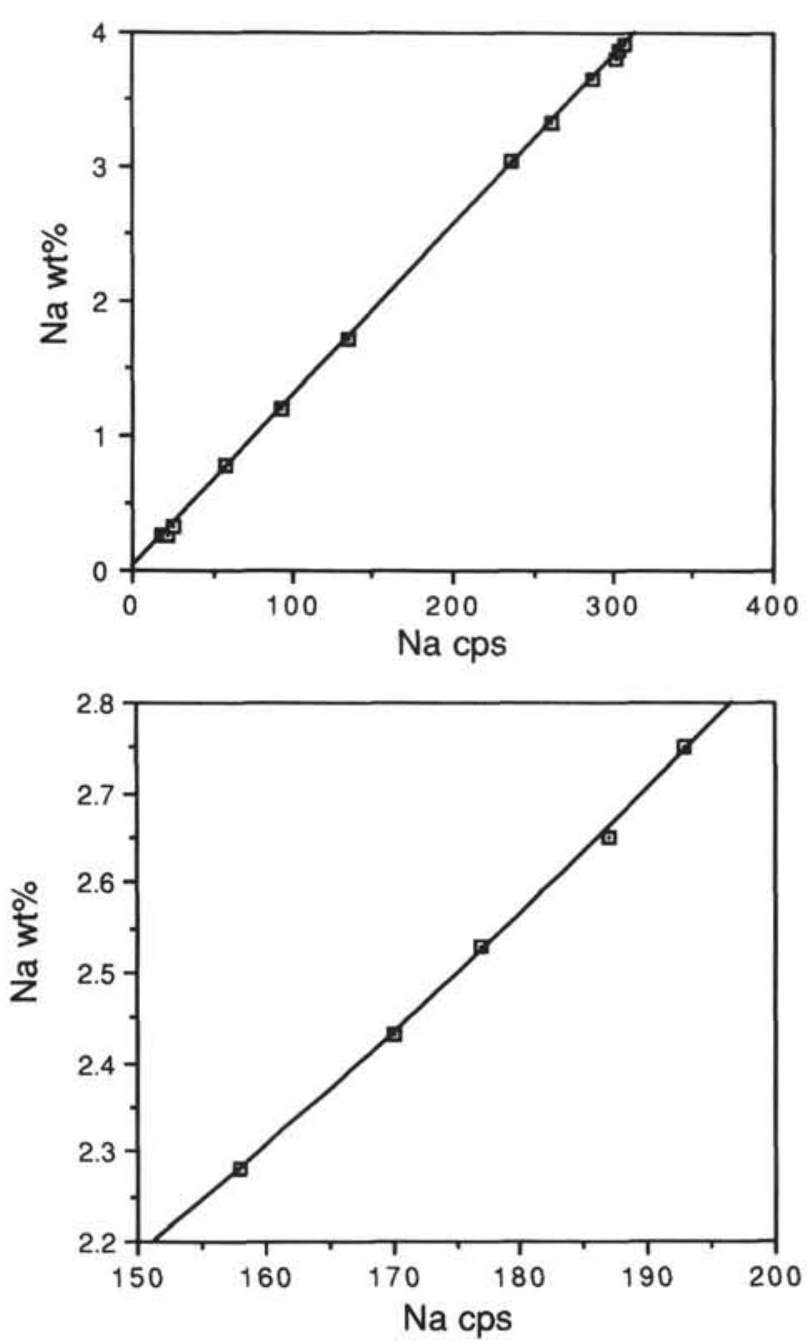

Figure 3. Graphs showing calibration line of sodium contents (wt\%) for the sodium counts (cps). The upper graph is for acidic glass, the lower graph for intermediate glass. Potassium calibration line accidentally coincides with that of sodium.

Hokkaido University. In this case, accelerating voltage was 10 or $20 \mathrm{kV}$ and beam current $2 \times 10^{-9} \AA$. In the glass inclusions, microglobules were observed under the microscope in all of the samples. They are thought to have been bubbles filled with a gaseous phase, but they are now mostly filled by polishing powder or dust under the microscope. Therefore, it is impossible to estimate their composition.

\section{OCCURRENCE AND CHEMICAL COMPOSITION OF GLASS INCLUSIONS}

\section{Sample A}

Plagioclase contains many irregularly shaped (including rectangular, square, and round) glass inclusions (Plate 1, Figs. 1, 2, and 4). We analyzed a few glass inclusions in plagioclase phenocrysts. Most of the inclusions solidified to brown glass and sometimes they had dark quench crystals. The inclusions often showed unmixed textures, a complicated pattern of dark- and light-colored areas such as myrmekite (Plate 1, Figs. 1 and 2). Each area was too fine to analyze. Therefore, one analysis of a glass inclusion (glass in plagioclase, Table 2) included both unmixed parts.
By means of semiquantitative EDS analysis, it was revealed that one part of the sample (white area in Plate 1, Fig. 2) contains high $\mathrm{Mg}, \mathrm{Fe}$, and low $\mathrm{Si}$ as compared with the dark part, which has a somewhat similar composition to the glass inclusions in the plagioclase of Samples B and C. The lack of mixing may indicate immiscible liquids in plagioclase phenocrysts (Philpotts, 1981, 1982). Around the unmixed glass inclusions, small, clear silicic glass inclusions with microglobules occur (Plate 1, Fig. 1). These inclusions seem to have been trapped later than the former inclusions, showing an unmixed texture. The mechanism that forms two kinds of inclusions is not fully understood.

Approximately oval-shaped, dispersed, and comparatively large glass inclusions were observed in pyroxene (Plate 1, Fig. 3). The inclusions often contain a single microglobule in each and are pale brownish in color. The glass composition (Table 2) is different from normal dacite and/or host andesite, which suggests that the glass is a residue of trapped liquid during pyroxene crystallization. $\mathrm{K}_{2} \mathrm{O}$ occurs selectively in glass inclusions.

The $\mathrm{Mg} /(\mathrm{Mg}+\mathrm{Fe})$ ratios in the inclusions are variable, as these were affected during pyroxene crystallization, but the $\mathrm{Ca} /(\mathrm{Ca}+\mathrm{Na})$ ratios are comparatively constant. The high ratio is equivalent to that of a liquidus composition formed by the crystallization of calcic plagioclase (An $80 \%-85 \%$ ).

\section{Sample B}

Glass inclusions were commonly observed in plagioclase phenocrysts; they are mostly oval-shaped or rectangular. They occur irregularly along the inner parts of plagioclase and are arranged along a crystal plane (Plate 1, Fig. 5). The range of An in the host plagioclase varies from $74 \%$ to $85 \%$, and the An of the plagioclase adjacent to inner glass inclusions is as low as $74 \%$. Similar enhancement of sodium around glass inclusions was described by Watson (1976). As shown in Plate 1, Figure 5, a rhythmical zoning pattern was observed only in the part of the crystal without glass inclusions-mostly the outer rim. A minute grain of clinopyroxene occurs within a glass inclusion. Glass inclusions are compositionally high in $\mathrm{SiO}_{2}$ and $\mathrm{K}_{2} \mathrm{O}$ contents (Table 3$) . \mathrm{Ca} /(\mathrm{Ca}+\mathrm{Na})$ ratios in the inclusions are variable $(0.2-0.32)$, but the $\mathrm{Mg} /(\mathrm{Mg}+\mathrm{Fe})$ ratios are rather constant $(0.27-$ 0.30 ). These occurrences and compositional characteristics of the glass inclusions suggest that they were trapped during the crystal growth stage of plagioclase and represent a residual composition after reaction with host plagioclase.

\section{Sample C}

In this sample, glass inclusions were also found in the plagioclase; oval-shaped and coarse inclusions occur mostly on the inner side of the plagioclase, which suggests rapid crystal growth of the inner plagioclase.

A microglobule in each inclusion occurred in the central part of plagioclase (Plate 2, Figs. 1 and 2) and can occupy over $20 \%$ of the inclusions in terms of volume. These inclusions are coarser than those in the marginal inclusions and in pyroxene. This suggests that gaseous phases were comparatively predominant during the early crystallization stage of the plagioclase. The composition is similar to that of Sample B.

\section{Sample D}

A coarse clinopyroxene crystal in Sample D includes glass inclusions that are arranged in inner and outer rows (Plate 2, Fig. 3). The clinopyroxene is compositionally rather homogeneous, but adjacent to areas near the outer inclusions, the pyroxene is slightly rich in $\mathrm{CaO}$ (numbers 3, 4, and 14 in Fig. 4). The pyroxene also contains anhedral 
plagioclase inclusions. The compositions of the glass inclusions are classified into two groups on the basis of their $\mathrm{TiO}_{2}$ and $\mathrm{CaO}$ contents and $\mathrm{Mg} /(\mathrm{Mg}+\mathrm{Fe})$ ratio (Fig. 5). The inner inclusions are high in $\mathrm{TiO}_{2}$ and low in $\mathrm{CaO}$ and $\mathrm{Mg} /(\mathrm{Mg}+\mathrm{Fe})$, indicating evolved magmatic liquid, as compared with the outer inclusions. Although these components and their ratio may be influenced during the crystallization of host clinopyroxene, their compositions seem not to have been substantially modified during crystallization. The glass inclusions plot on an extension of a fractionation trend on the $\mathrm{CaO}-\mathrm{MgO}-\mathrm{Al}_{2} \mathrm{O}_{3}$ diagram (Fig. 6) of Watson (1976). The outer inclusions, which were trapped at a later stage of pyroxene crystallization, are higher in $\mathrm{CaO}$ and $\mathrm{Mg} /(\mathrm{Mg}+\mathrm{Fe})$ and lower in $\mathrm{TiO}_{2}$. This is a paradox for closedsystem crystallization models, for the compositional changes in the residual liquid caused by the crystallization of clinopyroxene and other ferromagnesian minerals would produce the opposite effect.

\section{DISCUSSION AND CONCLUSIONS}

As described by Philpotts (1982), silica-rich glass typically forms a continuous phase that encloses iron-rich globules. Therefore, unmixed glass as described in Sample A does not commonly occur. Immiscible liquid preserved in glass inclusions in a basalt as an exception was described by Philpotts (1981). He reported that magnesium-rich glass occurs in small spheres of clear silicarich glass. The lack of mixing was interpreted as being a metastable occurrence. However, immiscible liquid preserved as glass globules in the mesostasis of volcanic glass is commonly observed, as described by Philpotts (1982).

The unmixed glasses indicate variable magma-mixing processes (Philpotts, 1982). However, unmixed glasses that occur in the Sample A inclusions do not indicate magma mixing. This lack of mixing indicates that trapped glasses became differentiated as magnesium- and silica-rich glass after plagioclase crystallization. Such lack of mixing was not observed in the andesite of Samples B and C. Thus, we consider that liquid immiscibility plays an important role in the differentiation of a high-magnesian andesite. The groundmass in Sample A forms a small-scale layering of light- and dark-colored matrix. This may also be evidence for the lack of mixing in glass.

$\mathrm{The} \mathrm{Ca} /(\mathrm{Ca}+\mathrm{Na})$ ratio of glass inclusions in pyroxene of Sample $\mathrm{A}$ is equivalent to that of the residue after calcic ( $\mathrm{An}=$ around $80 \%$ ) plagioclase crystallization under low-pressure conditions (e.g., Fig. 7 in Johannes, 1989, and so on). However, the ratio is not as high as that of the glass inclusions in olivine phenocrysts from Tonga (Fallon and Green, 1986). This may indicate that in a high-magnesian andesite the magma was rich in $\mathrm{CaO}$ and orthopyroxene crystallized earlier than plagioclase.

Occurrences of larger glass inclusions and comparatively large globules in them in the inner part of calcic plagioclase from Sample C and also Sample B suggest rapid growth of calcic plagioclase in a magmatic liquid rich in gaseous components. The calcic composition of the plagioclase may result in part from the crystallization of a liquid rich in volatiles.

In a pyroxene of Sample D, outer glass inclusions suggest crystallization from a relatively unevolved magma. The compositions of both inner and outer inclusions plot along a fractionation trend, as shown in Figure 5. Therefore, during the later crystallization stage of clinopyroxene, the pyroxene was surrounded by less fractionated magma. This could have resulted either from magma mixing or from gravitational sinking of pyroxene to the bottom of the magma chamber.

In this chapter we have described the chemical composition of glass inclusions in andesitic rocks. Some element ratios indicate the degree of crystallization and provide information on the complicated crystallization processes.

The following conclusions result from our preliminary study:

1. Liquid immiscibility was observed in glass inclusions in plagioclase phenocrysts of a high-magnesian andesite, which suggests the important role of liquid immiscibility for the differentiation of high-magnesian andesites.

2. Judging from the occurrence of glass inclusions with larger globules, a higher vapor content is suggested during an early stage of plagioclase crystallization of andesite.

3. From an analysis of the glass inclusions of a clinopyroxene, at least two different liquids appear to have been present as the crystal grew. Less fractionated liquid was trapped in the outer portion of the pyroxene, indicating magma mixing before the later stages of crystal growth.

\section{ACKNOWLEDGMENTS}

The authors would like to express our sincere thanks to Dr. C. H. Langmuir, Lamont-Doherty Geological Observatory of Columbia University, for his kind and valuable comments. We also would like to extend our thanks to Dr. M. R. Fisk for his critical reading of our manuscript in an early stage, and Dr. J. Yajima, Geological Survey of

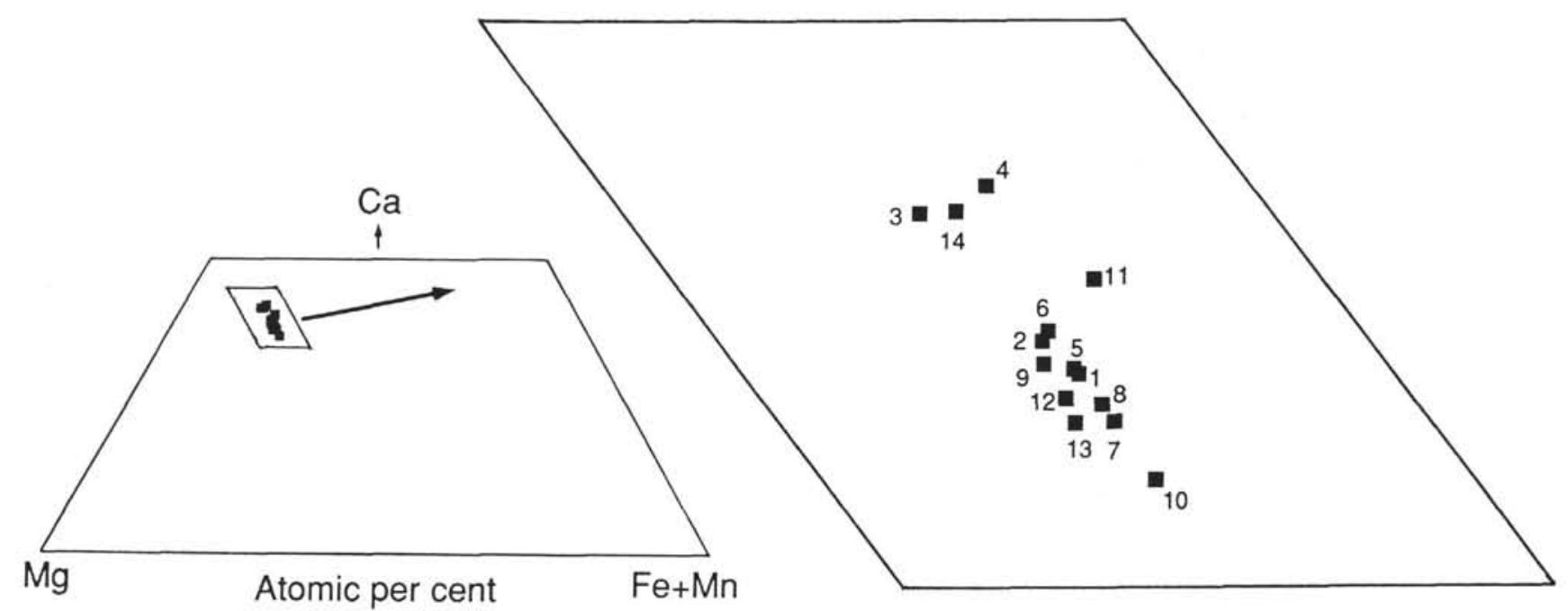

Figure 4. Chemical composition of clinopyroxene plotted on a diopside-hedenbergite-enstatite-ferrosilite diagram. Numbers correspond to those in Table 5 and Plate 2, Figure 3. 
Table 2. Chemical composition of plagioclase, orthopyroxene, and glass inclusions in plagioclase and orthopyroxene in Sample A (Site 793, high-magnesian andesite).

\begin{tabular}{|c|c|c|c|c|c|c|c|c|c|c|}
\hline \multirow[b]{2}{*}{ Number } & \multicolumn{7}{|c|}{ Plagioclase } & \multirow[b]{2}{*}{ Orthopyroxene } & \multirow{2}{*}{$\begin{array}{c}\text { Plagioclase } \\
\text { in orthopyroxene }\end{array}$} & \multirow{2}{*}{$\begin{array}{c}\text { Glass } \\
\text { in plagioclase }\end{array}$} \\
\hline & 1 & 2 & 3 & 4 & 5 & 6 & 7 & & & \\
\hline \multicolumn{11}{|c|}{ Major elements (wt\%): } \\
\hline $\mathrm{SiO}_{2}$ & 47.12 & 49.42 & 49.27 & 48.32 & 49.41 & 49.26 & 49.01 & 55.12 & 49.36 & 66.45 \\
\hline $\mathrm{TiO}_{2}^{2}$ & 0.00 & 0.00 & 0.02 & 0.01 & 0.01 & 0.01 & 0.06 & 0.08 & 0.01 & 0.53 \\
\hline $\mathrm{Al}_{2} \mathrm{O}_{3}$ & 33.25 & 31.64 & 31.77 & 32.63 & 31.96 & 32.04 & 32.74 & 0.84 & 32.41 & 9.96 \\
\hline $\mathrm{FeO}$ & 0.76 & 0.71 & 0.73 & 0.71 & 0.78 & 0.78 & 0.90 & 15.35 & 1.11 & 8.98 \\
\hline $\mathrm{MnO}$ & 0.03 & 0.01 & 0.06 & 0.00 & 0.00 & 0.00 & 0.01 & 0.40 & 0.00 & 0.10 \\
\hline $\mathrm{MgO}$ & 0.06 & 0.14 & 0.13 & 0.11 & 0.13 & 0.16 & 0.10 & 26.31 & 0.13 & 3.03 \\
\hline $\mathrm{CaO}$ & 17.26 & 15.47 & 15.89 & 16.65 & 15.97 & 15.74 & 16.46 & 1.92 & 15.82 & 3.99 \\
\hline $\mathrm{Na}_{2} \mathrm{O}$ & 1.45 & 2.46 & 2.10 & 1.68 & 2.04 & 1.99 & 1.85 & 0.04 & 2.14 & 2.80 \\
\hline $\mathrm{K}_{2} \mathrm{O}$ & 0.00 & 0.02 & 0.04 & 0.01 & 0.03 & 0.02 & 0.04 & 0.00 & 0.02 & 1.08 \\
\hline Total & 99.93 & 99.87 & 100.01 & 100.12 & 100.33 & 100.00 & 101.17 & 100.06 & 101.00 & 96.92 \\
\hline Mineral formula & & & & $0=8$ & & & & $0=6$ & $0=8$ & \\
\hline \multicolumn{11}{|c|}{ Trace elements (ppm): } \\
\hline $\mathrm{Si}$ & 2.170 & 2.265 & 2.256 & 2.214 & 2.255 & 2.254 & 2.223 & 1.988 & 2.241 & \\
\hline Al & 1.805 & 1.709 & 1.715 & 1.762 & 1.719 & 1.728 & 1.751 & 0.036 & 1.735 & \\
\hline $\mathrm{Ti}$ & 0.000 & 0.000 & 0.001 & 0.000 & 0.000 & 0.000 & 0.002 & 0.002 & 0.000 & \\
\hline $\mathrm{Fe}$ & 0.029 & 0.027 & 0.028 & 0.027 & 0.030 & 0.030 & 0.034 & 0.463 & 0.042 & \\
\hline $\mathrm{Mn}$ & 0.001 & 0.001 & 0.002 & 0.000 & 0.000 & 0.000 & 0.000 & 0.012 & 0.000 & \\
\hline $\mathrm{Mg}$ & 0.004 & 0.009 & 0.009 & 0.008 & 0.009 & 0.011 & 0.007 & 1.415 & 0.009 & \\
\hline $\mathrm{Ca}$ & 0.852 & 0.760 & 0.780 & 0.818 & 0.781 & 0.771 & 0.800 & 0.073 & 0.770 & \\
\hline $\mathrm{Na}$ & 0.129 & 0.218 & 0.186 & 0.149 & 0.180 & 0.176 & 0.163 & 0.002 & 0.180 & \\
\hline K & 0.000 & 0.001 & 0.003 & 0.001 & 0.002 & 0.001 & 0.002 & 0.000 & 0.001 & \\
\hline Total & 4.990 & 4.990 & 4.980 & 4.979 & 4.976 & 4.971 & 4.982 & 3.991 & 4.978 & \\
\hline $\mathrm{Ca} /(\mathrm{Ca}+\mathrm{Na})$ & 87 & 78 & 81 & 85 & 81 & 81 & 83 & 80 & & 44 \\
\hline $\mathrm{Mg} /(\mathrm{Mg}+\mathrm{Fe})$ & & & & & & & & & 75 & 38 \\
\hline
\end{tabular}

Note: Chemical composition in numbers 1 through 7 shows the variation of a plagioclase phenocryst from one side of the margin to the other through the central part (number 4 ).

Table 3. Chemical composition of plagioclase and glass inclusions in Sample B (Site 792).

\begin{tabular}{|c|c|c|c|c|c|c|c|c|c|c|}
\hline \multirow[b]{2}{*}{ Number } & \multicolumn{10}{|c|}{ Plagioclase } \\
\hline & 1 & 2 & 3 & 4 & 5 & 6 & 7 & 8 & 9 & 10 \\
\hline \multicolumn{11}{|c|}{ Major elements (wt\%): } \\
\hline $\mathrm{SiO}_{2}$ & 49.53 & 47.04 & 49.14 & 50.05 & 48.44 & 48.04 & 47.25 & 47.06 & 48.01 & 49.03 \\
\hline $\mathrm{TiO}_{2}$ & 0.00 & 0.00 & 0.00 & 0.05 & 0.00 & 0.00 & 0.00 & 0.04 & 0.02 & 0.01 \\
\hline $\mathrm{Al}_{2} \mathrm{O}_{3}$ & 31.56 & 32.86 & 32.03 & 31.59 & 32.12 & 32.49 & 33.08 & 33.02 & 32.34 & 31.68 \\
\hline $\mathrm{FeO}$ & 0.65 & 0.51 & 0.61 & 0.59 & 0.57 & 0.64 & 0.54 & 0.57 & 0.62 & 0.70 \\
\hline $\mathrm{MnO}$ & 0.02 & 0.00 & 0.04 & 0.03 & 0.01 & 0.06 & 0.00 & 0.02 & 0.05 & 0.00 \\
\hline $\mathrm{MgO}$ & 0.10 & 0.05 & 0.05 & 0.03 & 0.03 & 0.04 & 0.05 & 0.05 & 0.03 & 0.08 \\
\hline $\mathrm{CaO}$ & 15.82 & 16.98 & 15.97 & 15.16 & 15.73 & 16.35 & 17.00 & 16.86 & 16.30 & 15.61 \\
\hline $\mathrm{Na}_{2} \mathrm{O}$ & 2.54 & 1.59 & 2.38 & 2.90 & 2.08 & 1.96 & 1.60 & 1.66 & 2.10 & 2.38 \\
\hline $\mathrm{K}_{2} \mathrm{O}$ & 0.00 & 0.01 & 0.01 & 0.03 & 0.00 & 0.03 & 0.01 & 0.03 & 0.02 & 0.03 \\
\hline Total & 100.22 & 99.04 & 100.23 & 100.43 & 98.98 & 99.61 & 99.53 & 99.31 & 99.49 & 99.52 \\
\hline Mineral formula & \multicolumn{10}{|c|}{$\mathrm{O}=8$} \\
\hline \multicolumn{11}{|c|}{ Trace elements (ppm): } \\
\hline $\mathrm{Si}$ & 2.264 & 2.182 & 2.247 & 2.280 & 2.239 & 2.214 & 2.181 & 2.179 & 2.216 & 2.256 \\
\hline $\mathrm{Al}$ & 1.701 & 1.797 & 1.727 & 1.696 & 1.750 & 1.765 & 1.800 & 1.802 & 1.759 & 1.718 \\
\hline $\mathrm{Ti}$ & 0.000 & 0.000 & 0.000 & 0.002 & 0.000 & 0.000 & 0.000 & 0.001 & 0.001 & 0.000 \\
\hline $\mathrm{Fe}$ & 0.025 & 0.020 & 0.023 & 0.022 & 0.022 & 0.024 & 0.021 & 0.022 & 0.024 & 0.027 \\
\hline $\mathrm{Mn}$ & 0.001 & 0.000 & 0.001 & 0.001 & 0.000 & 0.002 & 0.000 & 0.001 & 0.002 & 0.000 \\
\hline $\mathrm{Mg}$ & 0.007 & 0.003 & 0.003 & 0.002 & 0.002 & 0.003 & 0.016 & 0.003 & 0.002 & 0.001 \\
\hline $\mathrm{Ca}$ & 0.775 & 0.844 & 0.783 & 0.740 & 0.779 & 0.807 & 0.841 & 0.836 & 0.806 & 0.770 \\
\hline $\mathrm{Na}$ & 0.225 & 0.143 & 0.211 & 0.256 & 0.187 & 0.175 & 0.143 & 0.149 & 0.188 & 0.212 \\
\hline $\mathrm{K}$ & 0.000 & 0.001 & 0.000 & 0.001 & 0.000 & 0.002 & 0.001 & 0.001 & 0.001 & 0.001 \\
\hline Total & 4.998 & 4.990 & 4.995 & 5.000 & 4.979 & 4.992 & 5.003 & 4.994 & 4.999 & 4.985 \\
\hline $\begin{array}{l}\mathrm{Ca} /(\mathrm{Ca}+\mathrm{Na}) \\
\mathrm{Mg} /(\mathrm{Mg}+\mathrm{Fe})\end{array}$ & 78 & 85 & 79 & 74 & 83 & 82 & 85 & 85 & 81 & 78 \\
\hline
\end{tabular}

Note: Numbers 1-15 correspond to those in Plate 1, Figure 5. 
Table 2 (continued).

\begin{tabular}{|c|c|c|c|c|c|}
\hline \multirow[b]{2}{*}{ Number } & \multicolumn{5}{|c|}{ Glass in orthopyroxene } \\
\hline & 1 & 2 & 3 & 4 & 5 \\
\hline \multicolumn{6}{|c|}{ Major elements (wt\%): } \\
\hline $\mathrm{SiO}_{2}$ & 68.69 & 67.64 & 67.62 & 67.41 & 67.70 \\
\hline $\mathrm{TiO}_{2}^{2}$ & 0.46 & 0.40 & 0.40 & 0.38 & 0.30 \\
\hline $\mathrm{Al}_{2} \mathrm{O}_{3}$ & 14.99 & 15.29 & 15.21 & 14.52 & 14.57 \\
\hline $\mathrm{FeO}$ & 3.30 & 3.79 & 3.68 & 5.07 & 5.10 \\
\hline $\mathrm{MnO}$ & 0.03 & 0.03 & 0.02 & 0.05 & 0.11 \\
\hline $\mathrm{MgO}$ & 0.43 & 0.49 & 0.49 & 0.98 & 0.91 \\
\hline $\mathrm{CaO}$ & 4.27 & 4.64 & 4.25 & 4.45 & 4.30 \\
\hline $\mathrm{Na}_{2} \mathrm{O}$ & 3.06 & 2.95 & 3.01 & 3.02 & 3.01 \\
\hline $\mathrm{K}_{2} \mathrm{O}$ & 0.96 & 0.83 & 0.94 & 0.87 & 0.93 \\
\hline Total & 96.19 & 96.06 & 95.62 & 96.75 & 96.93 \\
\hline \multicolumn{6}{|l|}{ Mineral formula } \\
\hline \multirow{2}{*}{\multicolumn{6}{|c|}{ Trace elements (ppm): }} \\
\hline & & \\
\hline \multirow{2}{*}{\multicolumn{6}{|c|}{$\begin{array}{l}\mathrm{Al} \\
\mathrm{Ti}\end{array}$}} \\
\hline $\mathrm{Ti}$ & & & & & \\
\hline \multicolumn{6}{|l|}{$\mathrm{Fe}$} \\
\hline \multicolumn{6}{|l|}{$\mathrm{Mn}$} \\
\hline \multicolumn{6}{|l|}{$\mathrm{Mg}$} \\
\hline \multicolumn{6}{|l|}{$\mathrm{Ca}$} \\
\hline \multicolumn{6}{|l|}{$\mathrm{Na}$} \\
\hline \multicolumn{6}{|l|}{$\mathrm{K}$} \\
\hline \multicolumn{6}{|l|}{ Total } \\
\hline $\mathrm{Ca} /(\mathrm{Ca}+\mathrm{Na})$ & 44 & 47 & 44 & 45 & 46 \\
\hline $\mathrm{Mg} /(\mathrm{Mg}+\mathrm{Fe})$ & 19 & 19 & 19 & 25 & 24 \\
\hline
\end{tabular}

Table 3 (continued).

\begin{tabular}{lrrrrr}
\hline & \multicolumn{5}{c}{ Glass } \\
\cline { 2 - 6 } Number & \multicolumn{1}{c}{11} & \multicolumn{1}{c}{12} & \multicolumn{1}{c}{13} & \multicolumn{1}{c}{14} & 15 \\
\hline Major elements (wt\%): & & & & & \\
$\mathrm{SiO}_{2}$ & 78.48 & 75.91 & 80.51 & 79.36 & 76.36 \\
$\mathrm{TiO}_{2}$ & 0.52 & 0.46 & 0.67 & 0.52 & 0.60 \\
$\mathrm{Al}_{2} \mathrm{O}_{3}$ & 9.03 & 10.08 & 8.88 & 9.44 & 9.13 \\
$\mathrm{FeO}$ & 3.68 & 3.29 & 3.30 & 3.16 & 4.62 \\
$\mathrm{MnO}$ & 0.07 & 0.07 & 0.09 & 0.10 & 0.08 \\
$\mathrm{MgO}$ & 0.77 & 0.72 & 0.72 & 0.75 & 0.95 \\
$\mathrm{CaO}$ & 1.76 & 2.14 & 1.74 & 1.77 & 1.86 \\
$\mathrm{Na} 2 \mathrm{O}$ & 2.20 & 4.46 & 2.05 & 3.05 & 4.35 \\
$\mathrm{~K}_{2} \mathrm{O}$ & 0.90 & 0.91 & 0.85 & 0.93 & 0.62 \\
& & & & & \\
$\mathrm{Total}$ & 97.41 & 98.04 & 98.81 & 99.08 & 98.57
\end{tabular}

Mineral formula

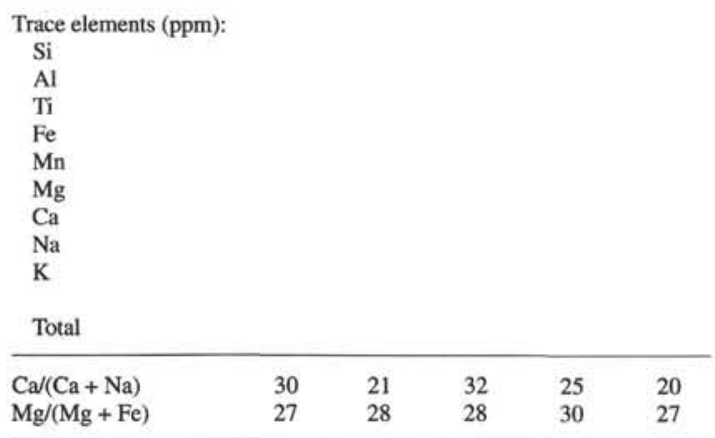

Table 4. Chemical composition of plagioclase and glass inclusions in Sample C (Site 792).

\begin{tabular}{|c|c|c|c|c|c|}
\hline \multirow[b]{2}{*}{ Number } & \multicolumn{4}{|c|}{ Plagioclase } & \multirow{2}{*}{$\begin{array}{c}\text { Glass } \\
5\end{array}$} \\
\hline & 1 & 2 & 3 & 4 & \\
\hline \multicolumn{6}{|c|}{ Major elements (wt\%): } \\
\hline $\mathrm{SiO}_{2}$ & 49.10 & 48.00 & 46.83 & 48.69 & 77.67 \\
\hline $\mathrm{TiO}_{2}$ & 0.01 & 0.02 & 0.03 & 0.01 & 0.68 \\
\hline $\mathrm{Al}_{2} \mathrm{O}_{3}$ & 31.74 & 32.46 & 33.08 & 31.84 & 8.67 \\
\hline $\mathrm{FeO}$ & 0.48 & 0.44 & 0.58 & 0.60 & 3.58 \\
\hline $\mathrm{MnO}$ & 0.03 & 0.03 & 0.01 & 0.02 & 0.12 \\
\hline $\mathrm{MgO}$ & 0.05 & 0.02 & 0.15 & 0.15 & 0.84 \\
\hline $\mathrm{CaO}$ & 15.62 & 16.46 & 17.36 & 15.86 & 1.80 \\
\hline $\mathrm{Na}_{2} \mathrm{O}$ & 2.42 & 1.96 & 1.37 & 2.07 & 3.81 \\
\hline $\mathrm{K}_{2} \mathrm{O}$ & 0.02 & 0.03 & 0.00 & 0.01 & 1.11 \\
\hline Total & 99.47 & 99.42 & 99.41 & 99.25 & 98.28 \\
\hline Mineral formula & \multicolumn{5}{|c|}{$\mathrm{O}=8$} \\
\hline \multicolumn{6}{|c|}{ Trace elements (ppm): } \\
\hline $\mathrm{Si}$ & 2.258 & 2.214 & 2.168 & 2.246 & \\
\hline $\mathrm{Al}$ & 1.721 & 1.765 & 1.805 & 1.731 & \\
\hline $\mathrm{Ti}$ & 0.000 & 0.001 & 0.001 & 0.000 & \\
\hline $\mathrm{Fe}$ & 0.018 & 0.017 & 0.022 & 0.023 & \\
\hline $\mathrm{Mn}$ & 0.001 & 0.001 & 0.000 & 0.001 & \\
\hline $\mathrm{Mg}$ & 0.003 & 0.002 & 0.010 & 0.010 & \\
\hline $\mathrm{Ca}$ & 0.770 & 0.814 & 0.861 & 0.784 & \\
\hline $\mathrm{Na}$ & 0.216 & 0.176 & 0.123 & 0.185 & \\
\hline K & 0.001 & 0.002 & 0.000 & 0.001 & \\
\hline Total & 4.988 & 4.992 & 4.990 & 4.981 & \\
\hline $\begin{array}{l}\mathrm{Ca} /(\mathrm{Ca}+\mathrm{Na}+\mathrm{K}) \\
\mathrm{Mg} /(\mathrm{Mg}+\mathrm{Fe})\end{array}$ & 78 & 82 & 88 & 81 & $\begin{array}{l}18 \\
30\end{array}$ \\
\hline
\end{tabular}

Note: Numbers 1-5 correspond to those in Plate 2, Figure 1.

Japan, for his kind comments. Dr. M. Nakagawa, Hokkaido University, and Dr. K. Wada, Hokkaido University of Education, also gave us useful suggestions. Encouragement and assistance from Professor Y. Katsui, Professor S. Yui, Dr. J. Maeda, and Ms. M. Ujiie, Hokkaido University, are also acknowledged.

\section{REFERENCES}

Anderson, A. T., 1973. The before-eruption water content of some high alumina magma. Bull. Volcanol., 37:530-552.

, 1982. Chlorine, sulfur and water in magma and oceans. Bull. Geol. Soc. Am., 85:1485-1492.

, 1976. Magma mixing: petrological process and volcanological tool. J. Volcanol. Geotherm. Res., 1:3-33.

Clocchiatti, R., and Massare, D., 1985. Experimental crystal growth in glass inclusions: the possibilities and limits of the method. Contrib. Mineral. Petrol., 89:193-204.

Dungan, M. A., and Rhodes, J. M., 1978. Residual glasses and melt inclusions in basalts from DSDP Legs 45 and 46: evidence for magma mixing. Contrib. Mineral. Petrol., 67:417-431.

Falloon, T. J., and Green, D. H., 1986. Glass inclusions in magnesian olivine phenocrysts from Tonga: evidence for highly refractory parental magmas in the Tonga Arc. Earth Planet. Sci. Lett., 81:95-103.

Honza, E., and Tamaki, K., 1985. The Bonin Arc. In Nairn, A.E.M., Stehli, F. G., and Uyeda, S. (Eds.), The Ocean Basins and Margins (Vol. 7): The Pacific Ocean: New York (Plenum), 459-502.

Johannes, W., 1989. Melting of plagioclase-quartz assemblages at $2 \mathrm{kbar}$ water pressure. Contrib. Mineral. Petrol., 103:270-276.

Komatsu, M., and Yajima, J., 1970. Chemical composition of glass inclusions in the phenocrysts of some volcanic rocks. Proc. Jpn. Acad., 46:7672-7677.

Ono, K., Okumura, K., and Soya, T., 1976. Volcanic glass analysis by EPMA. Ann. Meeting Sanko-gakkai (Soc.) Abstr. Programs, 117. 
Table 5. Chemical composition of clinopyroxene and plagioclase included in clinopyroxene and glass inclusions in Sample D (Site 792).

\begin{tabular}{|c|c|c|c|c|c|c|c|c|c|c|c|c|c|c|}
\hline \multirow[b]{2}{*}{ Number } & \multicolumn{14}{|c|}{ Clinopyroxene } \\
\hline & 1 & 2 & 3 & 4 & 5 & 6 & 7 & 8 & 9 & 10 & 11 & 12 & 13 & 14 \\
\hline \multicolumn{15}{|c|}{ Major elements (wt\%): } \\
\hline $\mathrm{SiO}_{2}$ & 52.53 & 52.09 & 52.57 & 52.66 & 52.31 & 52.65 & 52.45 & 52.44 & 52.61 & 52.21 & 52.13 & 52.54 & 52.32 & 51.67 \\
\hline $\mathrm{TiO}_{2}$ & 0.42 & 0.40 & 0.33 & 0.31 & 0.37 & 0.36 & 0.42 & 0.41 & 0.37 & 0.54 & 0.47 & 0.42 & 0.39 & 0.42 \\
\hline $\mathrm{Al}_{2} \mathrm{O}_{3}$ & 2.43 & 2.56 & 2.61 & 2.57 & 2.03 & 2.37 & 2.38 & 2.12 & 2.26 & 2.59 & 2.58 & 2.12 & 2.38 & 3.60 \\
\hline $\mathrm{FeO}$ & 9.00 & 8.47 & 7.00 & 7.39 & 9.00 & 8.70 & 9.55 & 9.43 & 8.64 & 10.05 & 8.62 & 9.07 & 9.29 & 7.23 \\
\hline $\mathrm{MnO}$ & 0.32 & 0.31 & 0.28 & 0.21 & 0.28 & 0.25 & 0.23 & 0.33 & 0.32 & 0.34 & 0.20 & 0.25 & 0.32 & 0.22 \\
\hline $\mathrm{MgO}$ & 15.92 & 15.85 & 16.10 & 15.75 & 15.99 & 16.13 & 15.81 & 16.09 & 15.99 & 15.89 & 15.47 & 16.02 & 16.21 & 15.79 \\
\hline $\mathrm{CaO}$ & 18.61 & 18.75 & 19.99 & 20.24 & 18.75 & 19.21 & 18.11 & 18.57 & 18.64 & 17.68 & 19.29 & 18.38 & 18.34 & 19.83 \\
\hline $\mathrm{Na}_{2} \mathrm{O}$ & 0.32 & 0.24 & 0.22 & 0.24 & 0.31 & 0.24 & 0.28 & 0.25 & 0.28 & 0.27 & 0.24 & 0.30 & 0.27 & 0.22 \\
\hline $\mathrm{K}_{2} \mathrm{O}$ & 0.00 & 0.00 & 0.00 & 0.00 & 0.00 & 0.00 & 0.00 & 0.00 & 0.00 & 0.00 & 0.00 & 0.00 & 0.00 & 0.00 \\
\hline Total & 99.55 & 98.67 & 99.10 & 99.37 & 99.04 & 99.91 & 99.23 & 99.64 & 99.11 & 99.57 & 99.00 & 99.10 & 99.52 & 98.98 \\
\hline \multicolumn{15}{|c|}{ Mineral formula } \\
\hline \multicolumn{15}{|c|}{ Trace elements (ppm): } \\
\hline $\mathrm{Si}$ & 1.948 & 1.946 & 1.947 & 1.950 & 1.953 & 1.946 & 1.953 & 1.948 & 1.957 & 1.941 & 1.945 & 1.957 & 1.943 & 1.919 \\
\hline $\mathrm{Al}$ & 0.106 & 0.113 & 0.114 & 0.112 & 0.089 & 0.103 & 0.105 & 0.093 & 0.099 & 0.114 & 0.114 & 0.093 & 0.104 & 0.158 \\
\hline $\mathrm{Ti}$ & 0.012 & 0.011 & 0.009 & 0.009 & 0.011 & 0.010 & 0.012 & 0.012 & 0.010 & 0.015 & 0.013 & 0.012 & 0.011 & 0.012 \\
\hline $\mathrm{Fe}$ & 0.279 & 0.265 & 0.217 & 0.229 & 0.281 & 0.269 & 0.297 & 0.293 & 0.269 & 0.313 & 0.269 & 0.283 & 0.289 & 0.225 \\
\hline $\mathrm{Mn}$ & 0.010 & 0.010 & 0.009 & 0.007 & 0.009 & 0.008 & 0.007 & 0.010 & 0.010 & 0.011 & 0.007 & 0.008 & 0.010 & 0.007 \\
\hline $\mathrm{Mg}$ & 0.880 & 0.883 & 0.889 & 0.869 & 0.890 & 0.888 & 0.878 & 0.891 & 0.886 & 0.881 & 0.860 & 0.890 & 0.897 & 0.874 \\
\hline $\mathrm{Ca}$ & 0.740 & 0.751 & 0.794 & 0.803 & 0.750 & 0.761 & 0.722 & 0.739 & 0.743 & 0.704 & 0.771 & 0.734 & 0.730 & 0.789 \\
\hline $\mathrm{Na}$ & 0.023 & 0.018 & 0.016 & 0.023 & 0.023 & 0.017 & 0.020 & 0.018 & 0.020 & 0.019 & 0.018 & 0.022 & 0.019 & 0.016 \\
\hline $\mathrm{K}$ & 0.000 & 0.000 & 0.000 & 0.000 & 0.000 & 0.000 & 0.000 & 0.000 & 0.000 & 0.000 & 0.000 & 0.000 & 0.000 & 0.000 \\
\hline Total & 3.998 & 3.997 & 3.995 & 4.002 & 4.006 & 4.002 & 3.994 & 4.004 & 3.994 & 3.998 & 3.997 & 3.999 & 4.003 & 4.000 \\
\hline
\end{tabular}

Note: Numbers 1-35 correspond to those in Plate 2, Figure 3.

Philpotts, A. R., 1981. Liquid immiscibility in silicate melt inclusions in plagioclase phenocrysts. Bull. Mineral., 104:317-324.

,- 1982 . Compositions of immiscible liquids in volcanic rocks. Contrib. Mineral. Petrol., 80:201-218.

Roedder, E., 1979. Origin and significance of magmatic inclusions. Bull. Mineral., 102:487-510.

Saitoh, G., and Kusakabe, M., 1989. Behavior of volatiles of magma during volcanic eruptions based on glass inclusion analysis: a review. Tech. Rep. Inst. Study Earth's Int. (ISEI), Ser. A, 27.

Shinohara, H., 1990. Behavior of volatiles in magma. Bull. Volcanol. Soc. Jpn. Second Ser., Special Number, Basic Studies of Volcanology, S99-S110.
Taylor, B., Fujioka, K., et al., 1990. Proc. ODP, Init. Repts., 126: College Station, TX (Ocean Drilling Program).

Watson, E. B., 1976. Glass inclusions as samples of early magmatic liquid: determinative method and application to a South Atlantic basalt. J. Volcanol. Geotherm. Res., 1:73-84.

Date of initial receipt: 2 January 1991

Date of acceptance: 19 August 1991

Ms 126B-126 
Table 5 (continued).

\begin{tabular}{|c|c|c|c|c|c|c|c|c|c|c|c|c|c|c|c|}
\hline \multirow[b]{2}{*}{ Number } & \multirow{2}{*}{$\begin{array}{c}\text { Plagioclase } \\
15\end{array}$} & \multicolumn{14}{|c|}{ Glass in clinopyroxene } \\
\hline & & 16 & 17 & 18 & 19 & 20 & 21 & 22 & 23 & 24 & 25 & 26 & 27 & 28 & 29 \\
\hline \multicolumn{16}{|c|}{ Major elements (wt\%): } \\
\hline $\mathrm{SiO}_{2}$ & 49.28 & 54.15 & 53.20 & 53.56 & 54.24 & 54.18 & 53.29 & 54.23 & 55.28 & 53.86 & 56.05 & 54.95 & 55.03 & 55.67 & 58.08 \\
\hline $\mathrm{TiO}_{2}^{2}$ & 0.03 & 1.03 & 1.05 & 0.98 & 0.96 & 1.02 & 0.92 & 1.07 & 0.90 & 0.93 & 0.91 & 1.13 & 1.17 & 1.25 & 1.12 \\
\hline $\mathrm{Al}_{2} \mathrm{O}_{3}$ & 31.68 & 15.16 & 14.65 & 15.07 & 15.57 & 15.32 & 14.88 & 15.50 & 16.06 & 15.13 & 16.13 & 15.77 & 15.40 & 14.97 & 15.69 \\
\hline $\mathrm{FeO}$ & 0.84 & 9.44 & 10.18 & 10.32 & 9.88 & 10.37 & 10.68 & 10.69 & 8.72 & 10.16 & 9.00 & 10.59 & 11.29 & 9.26 & 9.46 \\
\hline $\mathrm{MnO}$ & 0.00 & 0.20 & 0.25 & 0.17 & 0.22 & 0.20 & 0.27 & 0.17 & 0.22 & 0.21 & 0.18 & 0.25 & 0.21 & 0.19 & 0.21 \\
\hline $\mathrm{MgO}$ & 0.12 & 4.56 & 4.98 & 4.73 & 4.35 & 4.41 & 4.94 & 4.23 & 4.46 & 4.82 & 4.30 & 3.43 & 3.02 & 3.87 & 2.89 \\
\hline $\mathrm{CaO}$ & 15.49 & 8.20 & 8.51 & 8.18 & 7.91 & 8.12 & 8.37 & 7.86 & 8.52 & 8.13 & 8.15 & 7.38 & 7.97 & 7.43 & 6.24 \\
\hline $\mathrm{Na}_{2} \mathrm{O}$ & 2.59 & 2.44 & 2.28 & 2.43 & 2.53 & 2.78 & 2.47 & 2.95 & 2.55 & 2.44 & 2.27 & 3.00 & 3.81 & 2.66 & 2.66 \\
\hline $\mathrm{K}_{2} \mathrm{O}$ & 0.06 & 0.50 & 0.38 & 0.36 & 0.45 & 0.42 & 0.37 & 0.41 & 0.52 & 0.42 & 0.54 & 0.52 & 0.24 & 0.72 & 0.75 \\
\hline Total & 100.09 & 95.68 & 95.48 & 95.80 & 96.11 & 96.82 & 96.19 & 97.11 & 97.23 & 96.10 & 97.53 & 97.02 & 98.14 & 96.02 & 97.10 \\
\hline \multicolumn{16}{|c|}{ Mineral formula } \\
\hline \multicolumn{16}{|c|}{ Trace elements (ppm): } \\
\hline $\mathrm{Si}$ & 2.257 & & & & & & & & & & & & & & \\
\hline Al & 1.710 & & & & & & & & & & & & & & \\
\hline $\mathrm{Ti}$ & 0.001 & & & & & & & & & & & & & & \\
\hline $\mathrm{Fe}$ & 0.032 & & & & & & & & & & & & & & \\
\hline $\mathrm{Mn}$ & 0.000 & & & & & & & & & & & & & & \\
\hline $\mathrm{Mg}$ & 0.008 & & & & & & & & & & & & & & \\
\hline $\mathrm{Ca}$ & 0.760 & & & & & & & & & & & & & & \\
\hline $\mathrm{Na}$ & 0.230 & & & & & & & & & & & & & & \\
\hline $\mathrm{K}$ & 0.004 & & & & & & & & & & & & & & \\
\hline Total & 5.002 & & & & & & & & & & & & & & \\
\hline
\end{tabular}

Table 5 (continued).

\begin{tabular}{|c|c|c|c|c|c|c|}
\hline Number & 30 & 31 & 32 & 33 & 34 & 35 \\
\hline \multicolumn{7}{|c|}{ Major elements (wt\%): } \\
\hline $\mathrm{SiO}_{2}$ & 56.79 & 56.14 & 54.89 & 53.52 & 56.08 & 54.86 \\
\hline $\mathrm{TiO}_{2}$ & 1.17 & 1.27 & 1.13 & 1.23 & 1.27 & 1.10 \\
\hline $\mathrm{Al}_{2} \mathrm{O}_{3}$ & 15.45 & 14.24 & 13.84 & 13.90 & 14.24 & 13.88 \\
\hline $\mathrm{FeO}$ & 9.38 & 11.46 & 11.27 & 11.42 & 11.46 & 10.78 \\
\hline $\mathrm{MnO}$ & 0.16 & 0.19 & 0.18 & 0.20 & 0.19 & 0.19 \\
\hline $\mathrm{MgO}$ & 2.91 & 3.54 & 3.98 & 4.07 & 3.54 & 4.10 \\
\hline $\mathrm{CaO}$ & 6.32 & 6.94 & 7.07 & 7.27 & 6.94 & 7.29 \\
\hline $\mathrm{Na}_{2} \mathrm{O}$ & 2.75 & 2.68 & 2.46 & 2.21 & 2.68 & 2.28 \\
\hline $\mathrm{K}_{2} \mathrm{O}$ & 0.72 & 0.56 & 0.48 & 0.46 & 0.56 & 0.39 \\
\hline Total & 95.65 & 97.02 & 95.30 & 94.28 & 96.96 & 94.87 \\
\hline \multicolumn{7}{|c|}{ Mineral formula } \\
\hline \multicolumn{7}{|c|}{ Trace elements (ppm): } \\
\hline \multicolumn{7}{|c|}{$\mathrm{Si}$} \\
\hline \multicolumn{7}{|l|}{$\mathrm{Al}$} \\
\hline \multicolumn{7}{|l|}{$\mathrm{Ti}$} \\
\hline \multicolumn{7}{|l|}{$\mathrm{Fe}$} \\
\hline \multicolumn{7}{|l|}{$\mathrm{Mn}$} \\
\hline \multicolumn{7}{|l|}{$\mathrm{Mg}$} \\
\hline \multicolumn{7}{|l|}{$\mathrm{Ca}$} \\
\hline \multicolumn{7}{|l|}{$\mathrm{Na}$} \\
\hline \multicolumn{7}{|l|}{$\mathrm{K}$} \\
\hline Total & & & & & & \\
\hline
\end{tabular}



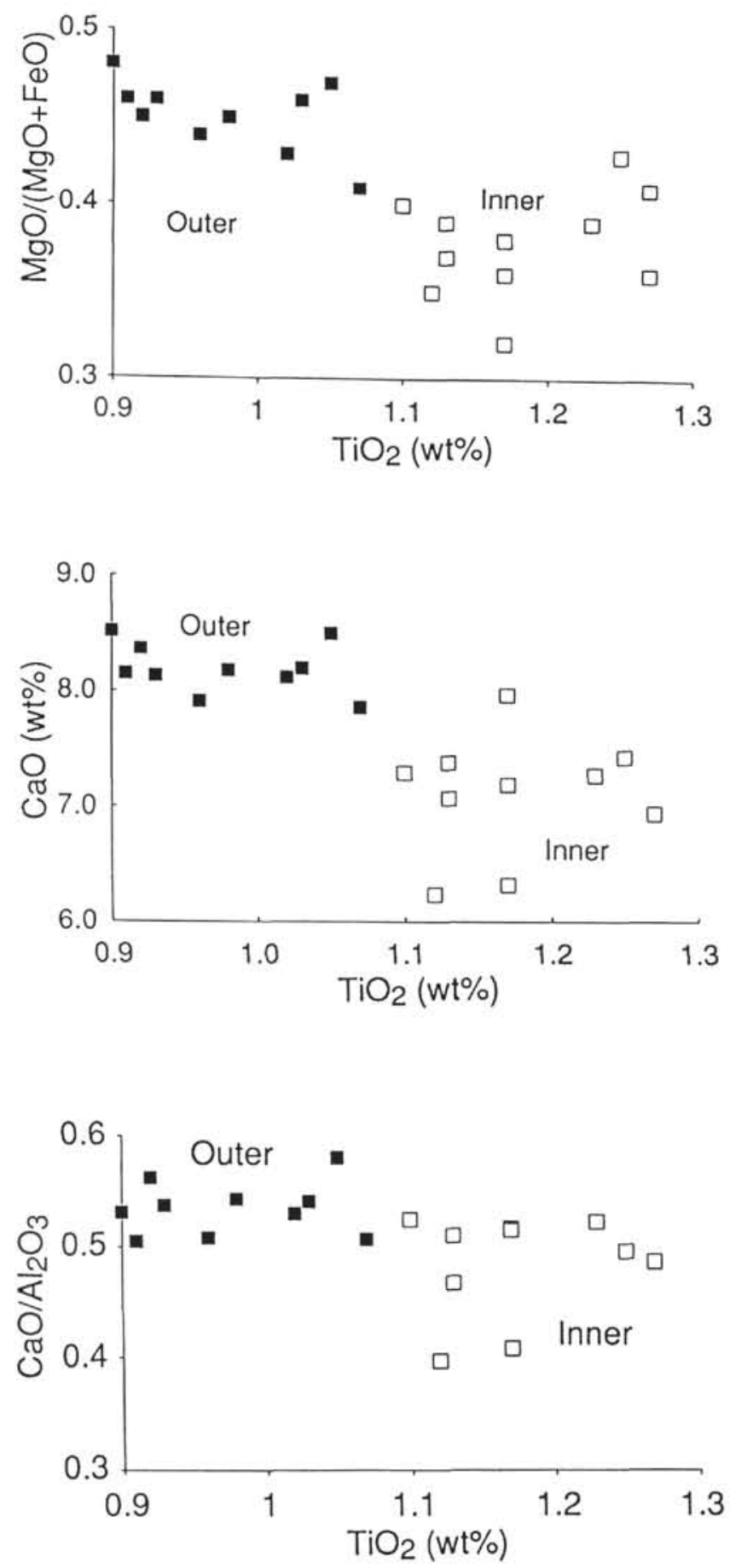

Figure 5. Glass composition from inner and outer inclusions in the clinopyroxene from Sample D. 


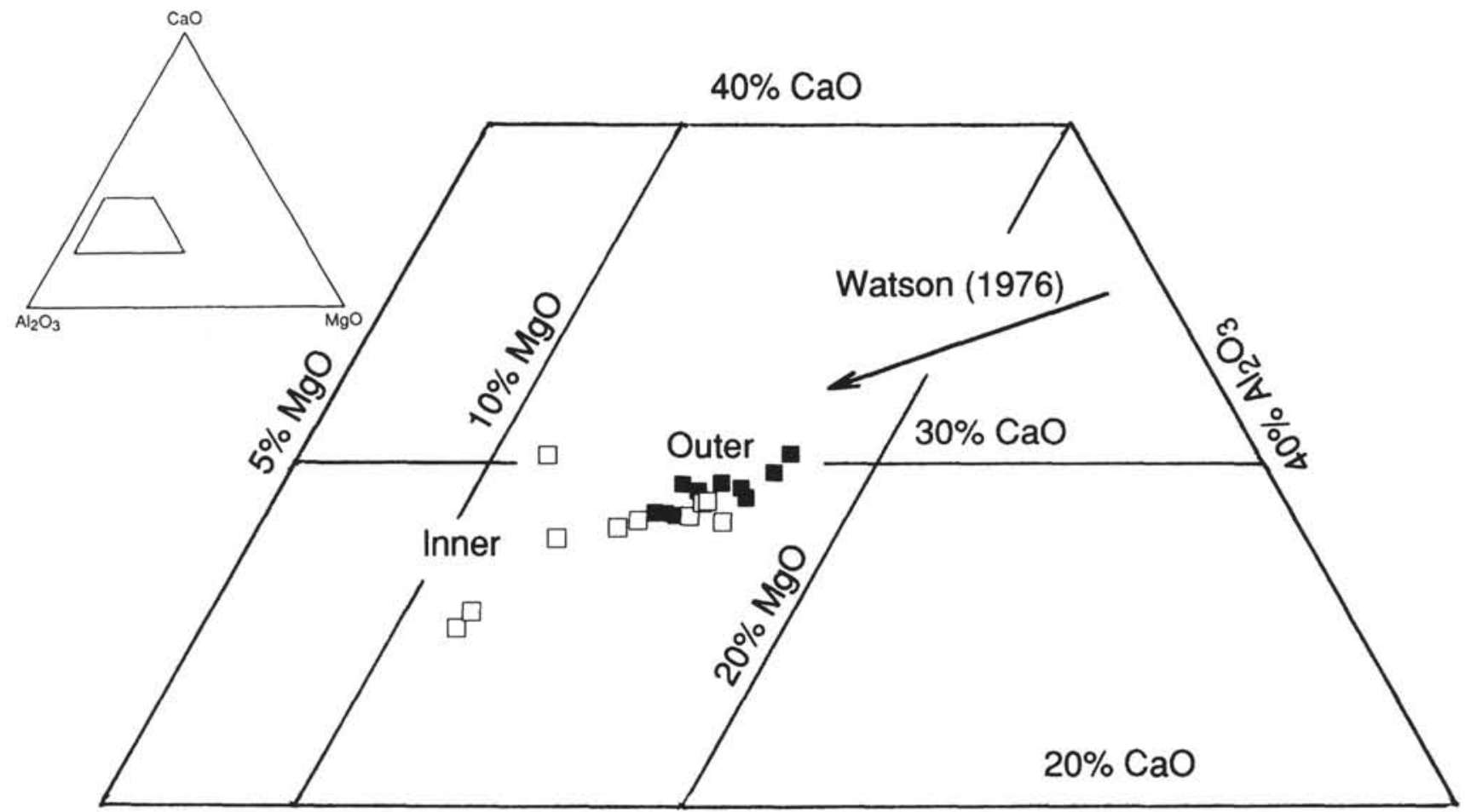

Figure 6. $\mathrm{CaO}-\mathrm{MgO}-\mathrm{Al}_{2} \mathrm{O}_{3}$ plot of glass inclusions in the clinopyroxene from Sample D. The arrow denotes the clinopyroxene fractionation line by Watson (1976). 

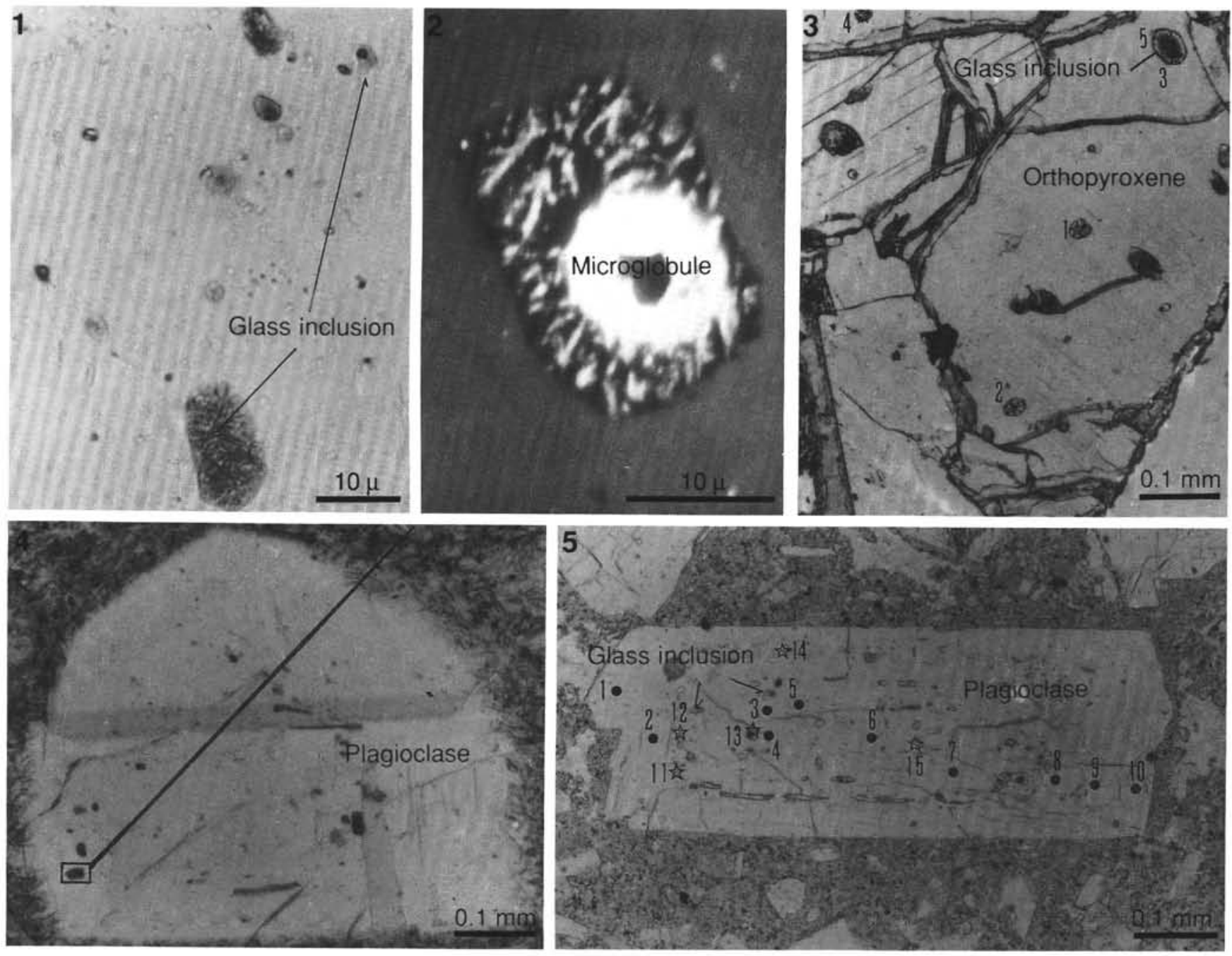

Plate 1. Occurrence of glass inclusions from Samples A and B. 1. Glass inclusion with unmixed texture observed under the microscope and silicic clear glass inclusions with microglobules (Sample A). 2. Secondary electron image of a glass inclusion with unmixed glass (Sample A). Light area is rich in Mg and Fe and poor in $\mathrm{Si}$ as compared to the dark area. The sphere was a bubble and has silicic wall. 3. An orthopyroxene phenocryst that includes glass inclusions (Sample A). 4. A plagioclase phenocryst that includes dark-colored glass inclusions (numbered 1-5) with unmixed texture (Sample A). 5. A plagioclase phenocryst that includes glass inclusions (numbered 1-15; see Table 3) (Sample B). 

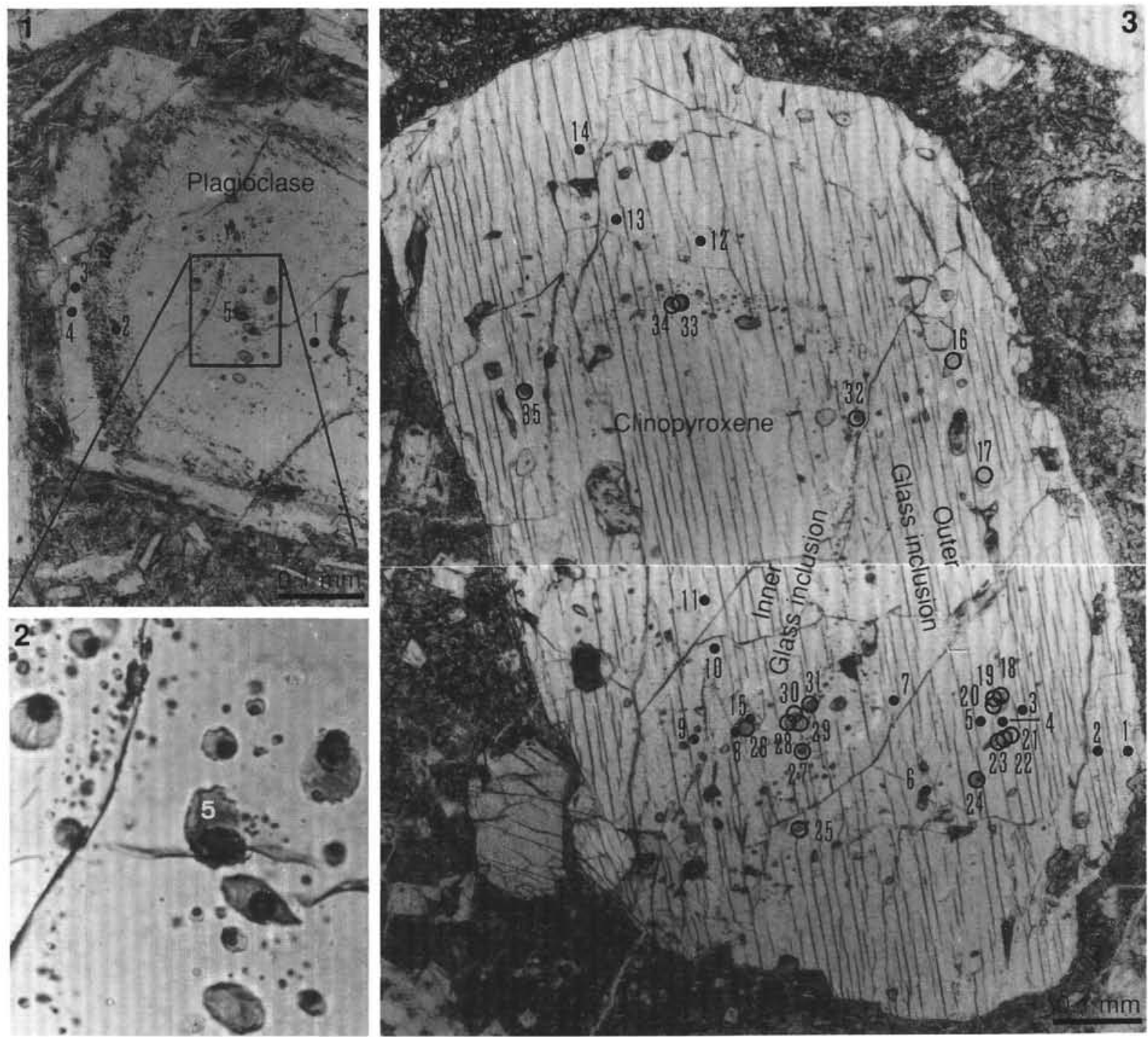

Plate 2. Occurrence of glass inclusions from Samples C and D. 1. A plagioclase phenocryst that contains larger glass inclusions (numbered 1-5; see Table 4) in the central part (Sample C). 2. Enlarged photomicrograph of the central part of a plagioclase phenocryst shown in Figure 1 (Sample C). 3. A clinopyroxene crystal with inner and outer rows of glass inclusions (numbered 1-35; see Table 5) (Sample D). 